\title{
Strategi Pengembangan Usaha Mikro Kecil dan Menengah (UMKM) Untuk Meningkatkan Perekonomian Masyarakat Desa di Desa Nembol Kecamatan Mandalawangi Kabupaten Pandeglang Banten
}

\author{
Riyanthi Idayu ${ }^{a}$, Mohamad Husni ${ }^{b}$, Suhandi ${ }^{c}$ \\ aniversitas Bina Bangsa, riyanthi.idayu@gmail.com \\ bUniversitas Bina Bangsa, mohamadhusni06@gmail.com \\ cUniversitas Bina Bangsa, suhandihitam@gmail.com
}

\begin{abstract}
A b s t r a k
Desa Nembol memiliki banyak potensi Usaha Mikro Kecil dan Menengah (UMKM) yang bersumber dari pertanian dan perkebunan. Penelitian ini bertujuan untuk menganalisa dan mengidentifikasi masalah yang dihadapi dan menysusn strategi dalam pengembangan Usaha Mirko Kecil dan Menengah (UMKM) yang ada di Desa Nembol Kecamatan Mandalawangi Pandeglang, sebagai salah satu sektor unggulan dalam membantu peningkatan perekonomian masyarakat Desa Nembol Kecamatan Mandalawangi Pandeglang. Metode Penelitian ini menggunakan metode kualitatif melalui proses observasi, wawancara, dan dokumentasi disajikan dalam bentuk data, kemudian analisa menggunakan analisis matrik SWOT untuk mengetahu kekuatan, kelemahan, peluang dan ancaman.Informan yang dijadikan sumber data terdiri dari Kepala Desa Nembol, Bumdes, Koperasi, pelaku umkm, Dinas UMKM Pandeglang dan Masyarakat Desa Nembol, waktu pelaksanaan penelitian satu tahun.Hasil penelitian ini menunjukan bahwa terdapat permasalahan pada setiap pelaku Usaha Mikro Kecil dan Menengah (UMKM) yang ada di Desa Nembol seperti: permodalan, produksi, pemasaran, sumber daya manusia, sarana dan prasarana, pengenalan teknologi, sosial dan ekonomi, sehingga pengembangan UMKM di Desa Nembol Kecamatan Mandalawangi belum bisa terlaksana dengan baik. Sedangkan strategi yang tepat dilakukan dalam pengembangan UMKM yang ada di Desa Nembol Kecamatan Mandalawangi Pandeglang adalah Strategi SO (Growth). Strategi SO (Growth) merupakan strategi yang memanfaatkan kekuatan yang ada untuk meningkatkan keunggulan kompetitifnya.
\end{abstract}

Kata Kunci: Strategi, pengembangan, UMKM, SWOT.

\section{A b s tract}

Nembol Village has a lot of potential for Micro, Small and Medium Enterprises (MSMEs) which are sourced from agriculture and plantations. This study aims to analyze and to identify the problems faced and formulate strategies in the development of Micro Small and Medium Enterprises (MSMEs) in Nembol Village, Mandalawangi District. Pandeglang, as one of the leading sectors in helping improve the economy of the people of Nembol Village. This research used qualitative method through a process of observation, interviews, and documentation presented in the form of data, then the data analysis used SWOT matrix analysis to find out the strengths, weaknesses, opportunities and threats. The informants used as the data source consisted of the Head of Nembol Village, Bumdes, Cooperatives, MSMEs actors, the Pandeglang MSMEs Office and the Nembol Village Community, the research implementation time is one year. The results of this study indicate that there are problems for every Micro, Small and Medium Enterprise (MSMEs) actor in Nembol Village such as: capital, production, marketing, resources human, facilities and infrastructure, the introduction of technology, social and economy, so that the development of MSMEs in Nembol Village, has not been implemented properly. While the right strategy for developing MSMEs in Nembol Village, Mandalawangi 
District, Pandeglang is the SO (Growth) Strategy. The SO (Growth) strategy is a strategy that utilizes existing strengths to increase its competitive advantage.

Keywords: Strategy, development, MSMEs, SWOT.

\section{Pendahuluan}

Usaha Mikro Kecil dan Menengah (UMKM) adalah kegiatan usaha yang dilakukan oleh orang perorangan atau kelompok yang bertujuan untuk mensejahterakan individu maupun kelompoknya. Usaha Mikro Kecil Mennegah (UMKM) memiliki peran strategis dalam pembangunan ekonomi nasional. dan juga dalam tumbuhnya ekonomi serta tenaga kerja dan distribusi hasil pembangunan. Usaha Mikro Kecil Menengah (UMKM) di desa dipandang memiliki prospek masa depan yang baik. Manfaat Usaha Mikro Kecil Menegah (UMKM) bagi perekonomian nasional antara lain: membuka lapangan pekerjaan, menjadi penyumbang terbesar nilai produk domestik bruto, salah satu solusi efektif bagi permasalahan ekonomi masyarakat kelas kecil dan menengah. Sedangkan manfaat Usaha Mikro Kecil Mennegah (UMKM) di desa bagi perekonomian daerah adalah meningkatkan pendapatan, memberdayakan masyarakat khususnya perempuan, mendapatkan pengalaman berwirausaha, memperkecil angka pengangguran di desa, mempererat rasa kebersamaan, mengembangkan potensi masyarakat, mengembangkan usaha yang telah ada sebelumnya, serta menumbuhkan rasa ingin maju dan sebagainya.

Desa Nembol adalah sebuah desa yang di kelilingi oleh pegunungan.Sebelah selatan Desa Nembol terdapat Gunung Pulosari, sebelah utara Desa Nembol terdapat Gunung Karang, sedangkan di sebelah barat terdapat Gunung Haseupan.Desa Nembol berbatasan dengan empat desa,yaitu Desa Cikoneng di sebelah barat,Desa Kurungkambing sebelah utara, Desa Giripawana di sebelah tenggara, dan disebelah timur berbatasan dengan Desa Kadubumbang Kecamatan Cimanuk yang di pisahkan oleh aliran sungai Cilemer.Disebelah selatan terdapat lahan milik Perhutani yang hampr keseluruhan lahan di tumbuhi pohon mahoni yang berada dalam kawasan Perhutani wliayah Gunung Pulosari,dengan luas desa : 295 Ha.

Pemilihan Desa Nembol yang dijadikan objek penelitian dibandingkan dengan desa lain yang berada di Kecamatan Mandalawangi Pandeglang, karena Desa Nembol memiliki banyak potensi produk UMKM baik dari hasil perkebunan, pertanian, dan kerajinan lainya seperti : keripik pisang, keripik singkong, kopi, keripik talas, sayuran, kerajinan anyaman bambu, anyaman dari daun pandan, ranginang dari beras ketan, rangining dari singkong, budi daya ikan mass, ikan lele, ikan mujair, budi daya kambing, dan lain sebagainya.Adapun produk terbaru bidang chemical hasil UMKM Desa Nembol yaitu: pelicin strika, detergen cair, foam sabun jely, sabun cuci pring, shampo steam, karbol pembersih kaca, hand shop, pupuk cair dan softener.

Berdasarkan hasil observasi, survai dan wawancara di lapangan dimana kondisi dan potensi yang di miliki Desa Nembol tersebut diatas, seharusnya keberadaan Usaha Mikro Kecil Menegah (UMKM) bisa untuk di kembangkan, namun kenyataan sampai sekarang masih pada jalan di tempat, bahkan ada yang sama sekali tidak berjalan alias tutup.Permasalahan yang di hadapi para pelaku Usaha Mikro Kecil Mennegah (UMKM) 
yang ada di Desa Nembol Kecamatan Mandalawangi Kabupaten Pandeglang adalah terkait permodalan dan pemasaran produk hasil olahan mereka.Selain itu pemberdayaan Usaha Mikro Kecil Menengah (UMKM) yang dilakukan Badan Usahan Milik Desa (BUMDES) dan Koperasi yang ada di Desa Nembol Kecamatan Mandalawangi Kabupaten Pandeglang, belum bisa memberikan hasil yang maksimal, terhadap perkembangan perekonomian di Desa Nembol Kecamatan Mandalangi Kabupaten Pandeglang itu sendiri.

Dalam rangka pengembangan UMKM di Desa Nembol Kecamatan Mandalangi Kabupaten Pandeglang, tidak bisa berjalan sendiri, melainkan harus ada kerja sama dengan beberapa pihak terkait di antanya: Kepala Desa, Dinas UMKM, Badan Usaha Milik Desa (BUMDES), Koperasi Desa, para pelaku UMKM, dan Masyarakat Desa Nembol itu sendiri, sementara sampai sekarang kondisi tersebut belum bisa terlaksana di Desa Nembol Kecamatan Mandalawangi Kabupaten Pandeglang.Dengan melihat kondisi tersebut diatas peneliti tertarik melakukan penelitian dengan judul Strategi Pengembangan UMKM Untuk Meningkatkan Perekonomian Masyarakat Desa di Desa Nembol Kecamatan Mandalawangi Kabupaten Pandeglang Banten. Bagaimana Strategi Pengembangan UMKM serta dampaknya dalam meningkatkan pertumbuhan ekonomi pedesaan di Desa Nembol Kecamatan Mandalawangi kabupaten Pandeglang. Untuk menganalisa dan mengkaji bagaimana penerapan strategi pengembangan UMKM, dalam rangka meningkatkan perekonomian masyarakat desa di Desa Nembol Kecamatan Mandalawangi Pandeglang.

\section{Landasan Teori}

\subsection{UMKM}

Usaha Mikro, Kecil dan Menengah (UMKM) memiliki peranan penting dan strategis dalam perekonomian di Indonesia. Peran penting UMKM tidak hanya berarti bagi pertumbuhan di kota - kota besar tetapi berarti juga bagi pertumbuhan ekonomi di pedesaan (Hamid \& Ikbal, 2017). Pemberdayaan UMKM sangat penting dan strategis dalam mengantisipasi perekonomian terutama dalam memperkuat struktur perekonomian nasional (Ukkas, 2017). Menurut Sugiyanto et al., (2021) bahwa UMKM merupakan salah satu sektor yang mempunyai peranan penting dalam pembangunan ekonomi. Sektor UMKM merupakan salah satu kekuatan utama dan vital yang mampu pendorong pembangunan ekonomi dan lapangan pekerjaan (Supardi et al., 2021). Pengembangan Usaha Kecil dan Menengah diharapkan dapat memberikan kontribusi yang besar terhadap pertumbuhan perekonomian sehingga perlu lebih diperhatikan karena mengemban misi menciptakan pemerataan kesempatan kerja dan berusaha, melestarikan budaya, dan mendukung ekspor nasional (Goso \& Bachri, 2016). Dengan demikian UMKM merupakan salah satu indikator utama yang dianggap mampu berkontribusi positif terhadap pertumbuhan ekonomi.

\subsection{Perekonomian Masyarakat Pedesaan}

Konsep pembangunan nasional yang diimplementasikan oleh pemerintah sebagai salah satu upaya dalam meningkatkan kesejahteraan masyarakat yaitu kebijakan membangun 
Indonesia dari desa (Fahrial, Tama \& Dewi, 2019). Ekonomi desa yaitu berbagai macam kegiatan mengandung unsur ekonomi yang dapat menjadi tumpuan bagi perputaran perekonomian di sebuah desa (Suhardjo, 2008). Artinya kegiatan yang dimaksud tidak hanya sebatas pada profesi petani. Pernyataan ini dianggap sesuai dengan gambaran kondisi pedesaan saat ini. Salah satu kiat untuk membangun desa yaitu dengan cara menumbuhkan jiwa entrepreneurship dan kreatifitas melalui pengembangan ekonomi dan industri kreatif (Hamid \& Ikbal, 2017). Dengan semakin berkembangnya teknologi, masyarakat desa tidak hanya berkutat pada profesi petani dan nelayan saja. Sebab berbagai macam sektor industri seperti pariwisata maupun industri kreatif, saat ini dapat menjadi tumpuan bagi peningkatan perekonomian di sebuah desa. Semakin berkembangnya sektor ini, lapangan pekerjaan di sebuah desa menjadi lebih bervariasi.

\section{Metode Penelitian}

Penelitan ini di pusatkan di kawasan Desa Nembol Kecamatan Mandalawangi Kabupaten Pandeglang Banten. Metode yang digunakan dalam penelitian ini adalah metode kualitatif deskriptif. Data dapat di peroleh melalui, observasi, wawancara, rekaman, dan lain sebagainya. Metode Analisis yang digunakan adalah analisis matriks SWOT. Metode analisis SWOT terdiri dari pengambungan unsure kekuatan (Strengths), kelemahan (Weaknesses), peluang (Opportunities), dan ancaman (Threats) yang mampu menghasilkan suatu strategi yang didasarkan pada situasi lingkungan internal dan eksternal (Qamaruddin et al., 2019). Penggunaan analisis SWOT diproyeksikan untuk mengetahui kekuatan, kelemahan, peluang dan ancaman yang dimiliki Desa Nembol terkait pengembangan keberadaan UMKM dalam rangka meningkatkan perekonomian masyarakat. Berdasarkan uraian diatas, maka peneliti menentukan informan dengan menggunakan teknik Snowball Sampling, yaitu pengambilan sample sumber data secara sengaja dan dengan pertimbangan tertentu. Dalam penelitian ini, maka peneliti menggunakan informan yang terdiri dari:

1. Kepala Dinas UMKM Pandeglang

2. Kepala Desa Nembol

3. Pegawai BUMBES

4. Pegawai Koperasi Desa Nembol

5. Para Pelaku UMKM Desa nembol

6. Masayarakat Desa Nembol.

\section{Hasil dan Pembahasan}

\subsection{Gambaran Karakteristik Objek Penelitian}

Usaha Mikro Kecil dan Menengah (UMKM) adalah kegiatan usaha yang dilakukan oleh orang perorangan atau kelompok yang bertujuan untuk mensejahterakan individu maupun kelompoknya. Usaha Mikro Kecil Mennegah (UMKM) memiliki peran strategis dalam pembangunan ekonomi nasional. dan juga dalam tumbuhnya ekonomi serta tenaga kerja dan distribusi hasil pembangunan. Usaha Mikro Kecil Menengah (UMKM) di desa dipandang memiliki prospek masa depan yang baik. Desa Nembol memiliki banyak 
potensi produk Usaha Mikro Kecil Menengah (UMKM) baik dari hasil perkebunan, pertanian, dan kerajinan lainya seperti:

\section{Tabel 1}

Daftar Potesni Usaha Mikro Kecil Menengah di Desa Nembol 2020

\begin{tabular}{|c|l|c|}
\hline No. & \multicolumn{1}{|c|}{ Nama Potensi UMKM } & Keterangan \\
\hline 1. & Keripik Pisang & Potensi Ekonomi \\
\hline 2 & Keripik Singkong & Potensi Ekonomi \\
\hline 3 & Kopi & Potensi Ekonomi \\
\hline 4 & Keripik talas & Potensi Ekonomi \\
\hline 5 & Opak Tepung Beras Ketan & Potensi Ekonomi \\
\hline 6 & Kerajinan anyaman bambu & Potensi Ekonomi \\
\hline 7 & Anyaman dari daun pandan & Potensi Ekonomi \\
\hline 8 & Ranginang dari beras ketan & Potensi Ekonomi \\
\hline 9 & Rangining dari singkong & Potensi Ekonomi \\
\hline 10 & Budi daya ikan mas, lele, dan mujair & Potensi Ekonomi \\
\hline 11 & Budi daya Kambing & Potensi Ekonomi \\
\hline 12 & Pelicin setrika & Potensi Ekonomi \\
\hline 13 & Sabun cuci piring & Potensi Ekonomi \\
\hline 14 & Foam sabu jely & Potensi Ekonomi \\
\hline 15 & Shampo steam & Potensi Ekonomi \\
\hline 16 & Karbol pembersih kaca & Potensi Ekonomi \\
\hline 17 & Hand shop & Potensi Ekonomi \\
\hline 18 & Pupuk cair & Potensi Ekonomi \\
\hline 19 & Softener pewangi pakain & Potensi Ekonomi \\
\hline
\end{tabular}

Sumber: data Desa Nembol Kecamatan Mandalawangi Pandeglang 2020.

Berdasarkan kondisi dan potensi yang di miliki Desa Nembol tersebut diatas, seharusnya keberadaan Usaha Mikro Kecil Menegah (UMKM) bisa untuk di kembangkan, namun kenyataan sampai sekarang masih pada jalan di tempat, bahkan ada yang sama sekali tidak berjalan alias tutup.Permasalahan yang di hadapi para pelaku Usaha Mikro Kecil Mennegah (UMKM) yang ada di Desa Nembol Kecamatan Mandalawangi Kabupaten Pandeglang adalah terkait permodalan dan pemasaran produk hasil olahan mereka.Selain itu pemberdayaan Usaha Mikro Kecil Menengah (UMKM) yang dilakukan Badan Usahan Milik Desa (BUMDES) dan Koperasi yang ada di Desa Nembol Kecamatan Mandalawangi Kabupaten Pandeglang, belum bisa memberikan hasil yang maksimal, terhadap perkembangan perekonomian di Desa Nembol Kecamatan Mandalangi Kabupaten Pandeglang itu sendiri.

\subsection{Hasil Wawancara dengan Informan}

Wawancara dilakukan dengan beberapa informan dengan tujuan untuk menggali informasi permasalahan yang terjadi terkait keberadaan Usaha Mikro Kecil dan Menengah yang ada di Desa Nembol Kecamatan Mandalawangi Pandeglang.Informan terdari dari : Para pelaku Usaha Mikro Kecil dan Menengah (UMKM), Kepala Desa 
Nembol, Aparat Desa Nembol, Bumdes, Koperasi, Masyarakat Desa Nembol dan Dinas Koperasi \& UMKM Pandeglang.

Tabel 2

Hasil wawancara dengan pihak terkait

\begin{tabular}{|c|c|c|c|}
\hline No. & $\begin{array}{c}\text { Nama Pihak } \\
\text { Terkait }\end{array}$ & Pertanyaan & Jawaban \\
\hline 1. & $\begin{array}{ll}\text { Kepala } & \text { Desa } \\
\text { Nembol } & \end{array}$ & $\begin{array}{l}\text { Sejauh mana } \\
\text { pengembangan keberadaan } \\
\text { UMKM di Desa Nembol? }\end{array}$ & $\begin{array}{l}\text { Selama ini masih berjalan seperti } \\
\text { biasa, dikarenakan keterbatasan } \\
\text { modal, sdm, pemasaran, } \\
\text { pengembangan UMKM di Desa } \\
\text { Nembol belum ada perkembangan } \\
\text { yang signipikan. }\end{array}$ \\
\hline 2 & $\begin{array}{l}\text { Sekretaris Desa } \\
\text { Nembol (Asep) }\end{array}$ & $\begin{array}{l}\text { Sejauh mana peran dari } \\
\text { aparat Desa Nembol , } \\
\text { terkait pengembangan } \\
\text { UMKM? }\end{array}$ & $\begin{array}{l}\text { Kami terus berupaya dalam } \\
\text { membantu pengembangan } \\
\text { UMKM yang ada di Desa Nembol, } \\
\text { sesuai dengan kemampuan yang } \\
\text { kami miliki, terutama, terkait } \\
\text { pendanaan, dan sumber daya } \\
\text { manusia. }\end{array}$ \\
\hline 3 & Pegawai BUMDES & $\begin{array}{lr}\text { Sejauh mana peran dari } \\
\text { Bumdes yang ada di Desa } \\
\text { Nembol, } \\
\text { pengembangan } \\
\text { yang ada di Desa N Nembol } \\
\text { itu sendiri? }\end{array}$ & $\begin{array}{l}\text { Kami dari pihak Bumdes, terus } \\
\text { berusaha untuk membantu } \\
\text { keberadaan UMKM yang ada di } \\
\text { Desa Nembol, namun kami } \\
\text { terbentur dengan permodalan, } \\
\text { sdm, dan pemasaran produknya. }\end{array}$ \\
\hline 4. & $\begin{array}{l}\text { Pegawai Koperasi } \\
\text { Unit Desa Nembol }\end{array}$ & $\begin{array}{l}\text { Sejauh mana peran dari } \\
\text { Koperasi Unit Desa } \\
\text { Nembol, dalam membantu } \\
\text { pengembangan keberadaan } \\
\text { UMK yang ada di Desa } \\
\text { Nembol? }\end{array}$ & $\begin{array}{l}\text { Pada intinya kami dari Koperasi } \\
\text { Unit Desa,sangat mensport } \\
\text { keberadaan UMKM yang ada di } \\
\text { Desa Nembol dengan memberikan } \\
\text { pinjaman atau kredit terkait } \\
\text { permodalan, namun kamipun } \\
\text { disini mengalamai kesulitan modal } \\
\text { usaha, dan banyak kredit macet di } \\
\text { yang belum di selesaikan, } \\
\text { sehingga menghambat berjalanya } \\
\text { usaha kami. }\end{array}$ \\
\hline 5 & $\begin{array}{l}\text { Pelaku Usaha } \\
\text { Keripik Pisang }\end{array}$ & $\begin{array}{l}\text { Sejauh mana usaha keripik } \\
\text { pisang yang sudah } \\
\text { bapak/ibu jalankan? }\end{array}$ & $\begin{array}{l}\text { Saya menjalankan usaha keripik } \\
\text { pisang sudah hampir lima tahun, } \\
\text { namun belum ada } \\
\text { perkembangannya, masalahnya } \\
\text { biasa terkait modal yang pas- } \\
\text { pasan, pemasaran nunggu yang } \\
\text { pesan aja. }\end{array}$ \\
\hline
\end{tabular}




\begin{tabular}{|c|c|c|c|}
\hline 6 & $\begin{array}{l}\text { Pelaku usaha budi } \\
\text { daya ikan (lele, } \\
\text { emas) }\end{array}$ & $\begin{array}{l}\text { Bagaimana usahanya } \\
\text { apakah ada perkembangan? }\end{array}$ & $\begin{array}{l}\text { Saya menjalankan usaha budi daya } \\
\text { ikan ( lele,emas, dll ) masih tetap } \\
\text { jalan di tempat, masalahnya seperti } \\
\text { biasa modal dan pemasaran } \\
\text { ikanya, selama ini modal habis } \\
\text { buat makan dan pemasaran } \\
\text { menunggu yang mau beli aja. }\end{array}$ \\
\hline 7 & Pelaku usaha Kopi & $\begin{array}{l}\text { Bagaimana perkembangan } \\
\text { usaha kopinya? }\end{array}$ & $\begin{array}{l}\text { Usaha kopi saya masih belum ada } \\
\text { perkembangan, karena terhambat } \\
\text { modal, proses produksi dan } \\
\text { pemasaran, jadi untuk sementara } \\
\text { usaha kopinya berjalan apa } \\
\text { adanya, ada yang pesan saya buat, } \\
\text { kalau ga ada yang pesan buat di } \\
\text { konsumsi sendiri. }\end{array}$ \\
\hline 8. & $\begin{array}{l}\text { Pelaku usaha sabun } \\
\text { cuci piring, } \\
\text { softener, hand shop. }\end{array}$ & $\begin{array}{l}\text { Bagaimana perkembangan } \\
\text { usahanya? }\end{array}$ & $\begin{array}{l}\text { Produk yang saya buat sementara } \\
\text { belum begitu banyak dan } \\
\text { pemasaranyapun masih sekitar } \\
\text { Desa Nembol, belum ada link } \\
\text { untuk pemasaran di luar Desa } \\
\text { Nembol. }\end{array}$ \\
\hline 9 & $\begin{array}{lr}\text { Pelaku } & \text { usaha } \\
\text { anyaman } & \text { dari } \\
\text { bambu dan pandan }\end{array}$ & $\begin{array}{l}\text { Faktor apa yang } \\
\text { menyebabkan usahanya } \\
\text { belum bisa berkembang? }\end{array}$ & $\begin{array}{l}\text { Biasa masalahnya di permodalan, } \\
\text { belum ada lembaga yang nampung } \\
\text { hasil kerajinan kita. }\end{array}$ \\
\hline 10 & $\begin{array}{l}\text { Masyarakat Desa } \\
\text { Nembol }\end{array}$ & $\begin{array}{l}\text { Sebagai bagian dari } \\
\text { masyarakat Desa Nembol, } \\
\text { bagaimana pendapatnya } \\
\text { terkait keberadaan UMKM } \\
\text { di Desa Nembol? }\end{array}$ & $\begin{array}{l}\text { Saya bangga sebagai warga Desa } \\
\text { Nembol, karena di Desa ini banyak } \\
\text { sekali potensi UMKM , namun } \\
\text { pengembangnya belum maksimal, } \\
\text { sehingga belum bisa membantu } \\
\text { meningkatkan perekonomian } \\
\text { masyarakat Desa Nembol itu } \\
\text { sendiri }\end{array}$ \\
\hline 11 & $\begin{array}{l}\text { Akademisi } \\
\text { Trisna Sonjaya } \\
\text { S.Pd., M.Pd. (Dosen } \\
\text { STIA Banten) }\end{array}$ & $\begin{array}{l}\text { Dari pihak Akademisi, } \\
\text { seperti apa pendapatnya } \\
\text { terkait pengembangan } \\
\text { UMKM di Desa Nembol? }\end{array}$ & $\begin{array}{l}\text { Saya melihat banyak sekali potensi } \\
\text { UMKM yang perlu di } \\
\text { kembangkan, dengan bekerjasama } \\
\text { dengan beberapa pihak sepeerti: } \\
\text { para pelaku umkm, Bumdes, } \\
\text { Koperasi, aparat Desa Nembol, } \\
\text { masyarkat Desa Nembol dan } \\
\text { Dinas Koperasi \& UMKM } \\
\text { Kabupaten Pandeglang }\end{array}$ \\
\hline 12. & $\begin{array}{l}\text { Dinas Koperasi \& } \\
\text { UMKM Kabupaten } \\
\text { Pandeglang. }\end{array}$ & $\begin{array}{l}\text { Bagaimana peran dari } \\
\text { Dinas Koperasi \& UMKM } \\
\text { Pandeglang, } \quad \text { terhadap }\end{array}$ & $\begin{array}{lrr}\text { Kami dari } & \text { Dinas } & \text { Koperasi \& } \\
\text { UMKM } & \text { Pandeglang, } & \text { tetap } \\
\text { mendukung } & \text { pengembangan }\end{array}$ \\
\hline
\end{tabular}




\begin{tabular}{|l|l|l|}
\hline & $\begin{array}{l}\text { keberadaan potensi UMKM } \\
\text { yang ada di Desa Nembol? }\end{array}$ & $\begin{array}{l}\text { keberadaan potensi UMKM yang } \\
\text { ada di Desa Nembol, dikarenakan } \\
\text { kondisi anggaran yang ada di } \\
\text { Dinas kami sangat terbatas, jadi } \\
\text { kami membantu sesuai dengan } \\
\text { kemampuan yang kami miliki. }\end{array}$ \\
\hline
\end{tabular}

\subsection{Hasil Penelitian}

Penelitian ini membahas tentang kondisi yang dialami oleh para pelaku UMKM pada kajian strategi sektor pengembangan di Desa Nembol Kecamatan Mandalawangi dilihat dari 10 (dsepuluh ) aspek yaitu permodalan, produksi, teknologi, pemasaran, SDM, birokrasi, sarana dan prasaran, serta sosial dan ekonomi, Kelembagaan, Peran Dinas terkait. Informasi terkait kesepuluh aspek tersebut dikumpulkan menggunakan metode kuisioner dan wawancara. Hasil yang diperoleh menunjukkan bahwa terdapat beberapa kendala yang dihadapi oleh UMKM Sektor Pengembangan di Desa Nembol Kecamatan Mandalawangi antara lain:

1. Pada aspek permodalan, sebagian UMKM masih menggunakan modal sendiri dan tidak menggunakan akses kredit karena kekhawatiran dalam hal pelunasan disamping sebagian besar tidak memiliki jaminan yang memadai.

2. Pada aspek produksi, sebagian besar UMKM masih menggunakan peralatan produksi yang sederhana, meskipun hal tersebut memberi keuntungan dalam hal biaya produksi yang terjangkau, namun peralatan yang masih tradisional menyebabkan produksi kurang efisien, khususnya apabila terdapat pesanan produksi dalam jumlah besar.

3. Pada aspek teknologi, sebagian besar UMKM belum terkomputerisasi dalam kegiatan operasional nya, seperti menerapkan pemasaran online.

4. Pada aspek pemasaran, sebagian besar UMKM belum mematenkan produk, belum terdapat diferensiasi produk dan belum memiliki kerjasama dengan perusahaan besar terkait bahan baku maupun penjualan produk.

5. Pada aspek sumber daya manusia, sebagian besar UMKM belum memiliki pengetahuan tentang pengelolaan keuangan yang ditandai dengan belum dipisahkannya keuangan pribadi dengan perusahaan.

6. Pada aspek birokrasi, sebagian besar UMKM kurang mengetahui regulasi terbaru yang diatur oleh pemerintah contohnya terkait perubahan undang-undang perpajakan.

7. Pada aspek sarana dan prasrana, sebagian UMKM kurang aktif dalam mengikuti program pemerintah dalam bentuk bantuan pendanaan dengan bunga lunak.

8. Pada aspek sosial ekonomi, sebagian besar UMKM kurang siap dengan perubahan kondisi ekonomi seperti ketidakstabilan politik dan pasar bebas dan kondisi pandemi covid-19.

9. Pada aspek kelembagaan, belum adanya lembaga yang mengelola keberadaan UMKM di Desa Nembol

10. Pada aspek peran Dinas terkait masih kurang peran dari Dinas terkait dalam proses produksi dan pemasaran produk hasil olahan UMKM Desa Nembol seperti: Dinas 
Koperaasi dan UMKM Kabupaten Pandeglang, Aparat Desa Nembol, Bumdes, Koperasi dan Masyarakat Desa Nembol itu sendiri..

Beberapa kendala yang dihadapi oleh UMKM menjadi perhatian utama dalam proses pembangunan inklusif yang dicanangkan oleh pemerintah, khususnya pemerintah daerah dalam rangka otonomisasi. Oleh karena itu, penelitian ini mencoba menganalisis strategi apa yang tepat dilakukan dalam mengembangkan UMKM khususnya pada Sektor Pengembangan di Desa Nembol Kecamatan Mandalawangi menggunakan analisis SWOT. Analisis SWOT dirasa tepat digunakan karena disamping melihat kekuatan dan peluang yang dimiliki oleh UMKM, dalam menentukkan strategi juga dilhat kelemahan dan ancaman yang akan dihadapi oleh UMKM. Indentifikasi masing-masing aspek dikelompokan dalam analisis SWOT untuk kemudian didapatkan matrik SWOT. Dalam menentukan strategi pengembangan UMKM di Desa Nembol, langkah pertama adalah identifikasi kondisi UMKM dalam 4 (empat) indikator yaitu Kekuatan (Strength), Kelemahan (Weekness), Peluang (Opportunities), dan Ancaman (Threats). Tabel 3 merupakan analisis pengelompokan indikator dalam empat kategori kekuatan, kelemahan, peluang, dan ancaman yang tertuang dalam matriks SWOT.

Hasil analisis SWOT menunjukan bahwa terdapat 10 (sepuluh) indikator kekuatan secara garis besar antara lain dalam aspek modal, bahan baku, tenaga kerja, peralatan produksi, kemasan, kualitas produk, promosi, pemasaran, dan asset. Sedangkan untuk indikator kelemahan terdapat 8 (delapan) antara lain dalam aspek bantuan modal, pengetahuan keuangan, peralatan produksi, diferensiasi produk, pemasaran, serta informasi pasar. Kemudian untuk analisis peluang, terdapat 8 (delapan) indikator antara lain akses kredit, bahan baku, legalitas produk, pelatihan tenaga kerja, keanggotaan asosiasi pengusaha, birokrasi, sarana dan prasarana. Sedangkan terdapat pula 5 (lima) ancaman antara lain aspek bantuan modal, relasi, pandemi covid-19, Inplasi . Dalam Tabel Matriks SWOT tersebut dirumuskan juga 4 (empat) strategi pengembangan berdasarkan identifikasi keempat indikator sebelumnya antara lain, strategi SO (Growth), strategi WO (Stability), strategi ST (Diversification), dan strategi WT (Defend). Untuk menentukan strategi mana yang tepat untuk pengembangan UMKM S di Desa Nembol Kecamatan Mandalawangi peneliti perlu melakukan analisis lebih lanjut melalui analisis kuantitatif yaitu dengan memberikan bobot dan rating pada masing-masing indikator.

\section{Tabel 3}

\section{Matriks Analisis SWOT}

\begin{tabular}{|c|c|c|}
\hline aktor Internal & $\begin{array}{l}\text { Strength (S) } \\
\text { 1. Modal milik sendiri } \\
\text { 2. Bahan Baku Mudah di } \\
\text { peroleh } \\
\text { 3. Kualitas bahan baku } \\
\text { konsisten } \\
\text { 4. Tenaga kerja otodidak } \\
\text { 5. Menerima Pesanan } \\
\text { 6. Biaya produksi } \\
\text { terjangkau }\end{array}$ & $\begin{array}{l}\text { Weakness (W) } \\
\text { 1. Tidak memiliki akses pada } \\
\text { lembaga keuangan } \\
\text { 2. Tidak memiliki pengalaman } \\
\text { dalam meminjam dana } \\
\text { 3. Tidak memiliki aset buat } \\
\text { jaminan } \\
\text { 4. Tidak dipisahkan keuangan } \\
\text { usaha dan pribadi }\end{array}$ \\
\hline
\end{tabular}




\begin{tabular}{|c|c|c|}
\hline ktor Ekst & $\begin{array}{l}\text { 7. Penjualan } \\
\text { konvensional } \\
\text { 8. Memiliki alat } \\
\text { transportasi } \\
\text { 9. Memiliki gudang } \\
\text { 10. Memiliki kemasan } \\
\text { baik }\end{array}$ & $\begin{array}{l}\text { 5. Peralatan produksi masih } \\
\text { sederhana } \\
\text { 6. Tidak memiliki merek yang di } \\
\text { patenkan } \\
\text { 7. Tidak memiliki tiem } \\
\text { pemasaran } \\
\text { 8. Tiak memilki informasi terkait } \\
\text { pemasaran }\end{array}$ \\
\hline $\begin{array}{l}\text { Opportunity (O) } \\
\text { 1. Mengtahui informasi } \\
\text { kredit } \\
\text { 2. Mencari pembelian bahan } \\
\text { baku yang lebih baik. } \\
\text { 3. Mencari pasar baru atau } \\
\text { peluang baru } \\
\text { 4. Mengikuti pelatihan } \\
\text { peningkatan keahlian } \\
\text { tenaga kerja } \\
\text { 5. Ikut serta dalam } \\
\text { kebijakan dan kegiatan } \\
\text { UMKM } \\
\text { 6. Mengikuti sistem } \\
\text { pemasaran dari kelompok } \\
\text { yang diikuti } \\
\text { 7. Ikut dalam pembinaan } \\
\text { program kemitraan } \\
\text { 8. Adanya peran Dinas } \\
\text { Koperasi \& UMKM } \\
\text { Pandeglang }\end{array}$ & $\begin{array}{l}\text { Strategi SO (Grwth) } \\
\text { 1. Mengikuti program } \\
\text { pengembangan } \\
\text { UMKM kredit lunak } \\
\text { utnuk menambah } \\
\text { modal usaha } \\
\text { 2. Menjaga hubungan } \\
\text { baik dengan mitra } \\
\text { penyedia bahan baku } \\
\text { 3. Menjaga hubungan } \\
\text { baik dengan karyawan } \\
\text { dan memberikan } \\
\text { pelatihan } \\
\text { 4. Melakukan } \\
\text { pengembangan produk } \\
\text { dengan menjaga } \\
\text { kualitas produk } \\
\text { 5. Melakukan pemasaran } \\
\text { dan promosi online } \\
\text { 6. Mengikuti program } \\
\text { pengmbangan UMKM } \\
\text { baik oleh pemerintah } \\
\text { atau swasta } \\
\text { 7. Menjaga aset dengan } \\
\text { baik }\end{array}$ & $\begin{array}{l}\text { Strategi WO (Stability) } \\
\text { 1. Mengikuti pelatihan } \\
\text { penigkatan kualitas produk } \\
\text { dan tenaga pembukuan } \\
\text { keuangan } \\
\text { 2. Mengikuti program } \\
\text { pengembangan UMKM kredit } \\
\text { rendah untuk menambah } \\
\text { modal usaha } \\
\text { 3. Melakukan pembaruan alat } \\
\text { produksi } \\
\text { 4. Melakukan pembelian secara } \\
\text { kredit } \\
\text { 5. Melakukan promosi dan } \\
\text { pemasaran online } \\
\text { 6. Mencari pasar baru dan } \\
\text { penyedia bahan baku yang } \\
\text { lebih besar } \\
\text { 7. Mengikuti program } \\
\text { pengembangan UMKM yang } \\
\text { diadakan baik oleh pemerintah } \\
\text { \& swasta }\end{array}$ \\
\hline $\begin{array}{l}\text { Threat }(\mathbf{T}) \\
\text { 1. Tidak ikut dalam } \\
\text { pendanaan bunga lunak } \\
\text { yang diberikan oleh } \\
\text { pemerintah } \\
\text { 2. Tidak memilki } \\
\text { hubungan dengan } \\
\text { pengusaha besar terkait } \\
\text { pembelian bahan baku } \\
\text { 3. Tidak memiliki } \\
\text { hubungan dengan } \\
\text { pengusaha besar terkait } \\
\text { penjualan produk }\end{array}$ & $\begin{array}{l}\text { Strategi } \\
\text { (Diversification) } \\
\text { 1. Mengikuti program } \\
\text { kemitraan UMKM } \\
\text { kredit lunak untuk } \\
\text { menambah modal } \\
\text { usaha } \\
\text { 2. Menjaga hubungan } \\
\text { baik dengan penyedia } \\
\text { bahan baku } \\
\text { 3. Menjaga hubungan } \\
\text { baik dengan karywan }\end{array}$ & $\begin{array}{l}\text { Strategi WT(Defend) } \\
\text { 1. Mengikuti program } \\
\text { pengembangan umkm dengan } \\
\text { bunga lunak untuk menambah } \\
\text { modal usaha } \\
\text { 2. Mengikuti pelatihan } \\
\text { peningkatan kualitas tenaga } \\
\text { kerja bagian pembukuan } \\
\text { keuangan } \\
\text { 3. Melakukan pembaruan alat } \\
\text { produksi yang canggih \& } \\
\text { efisien }\end{array}$ \\
\hline
\end{tabular}




\begin{tabular}{|c|c|c|}
\hline $\begin{array}{l}\text { 4. } \text { Kondisi pandemi } \\
\text { coovid-19, bisa } \\
\text { menghambat } \\
\text { perkembangan usaha } \\
\text { 5. Tingkat inflasi bisa } \\
\text { mempengaruhi } \\
\text { perkembangan usaha }\end{array}$ & $\begin{array}{l}\text { 4. } \begin{array}{l}\text { Menjaga kualitas } \\
\text { produk yang di } \\
\text { legalkan }\end{array} \\
\text { 5. Melakukan } \\
\text { pembaruan alat } \\
\text { produk yang lebih } \\
\text { canggih dan efisien } \\
\text { 6. Melakukan promosi } \\
\text { terhadap industri yang } \\
\text { lebih besar } \\
\text { 7. Menjga aset dengan } \\
\text { baik } \\
\text { 8. Memperharikan } \\
\text { kondisi pasar. }\end{array}$ & $\begin{array}{l}\text { 4. Melakukan diferensiasi } \\
\text { produk dan mematenkan } \\
\text { produk } \\
\text { 5. Melakukan promosi dan } \\
\text { memberikan pembayan kredit } \\
\text { 6. Melakukan promosi terhadap } \\
\text { industri yang lebih besar } \\
\text { 7. Memperhatikan kondisi pasar. }\end{array}$ \\
\hline
\end{tabular}

Berdasarkan hasil analisis SWOT diatas, maka didapatkan strategi pengembangan UMKM di Desa Nembol Kecamtan Mandalawangi Kabupaten Pandeglang, yang tepat adalah Strategi SO (Growth). Strategi SO merupakan strategi yang memanfaatkan kekuatan yang ada untuk meningkatkan keunggulan kompetitifnya.Melalui strategi SO (Growth) tersebut, UMKM yang ada di Desa Nembol Kecamatan Mandalawangi di harapkan menjalankan ekpansi pasar, memperbesar pertumbuhan produksi dan pengupayakan kemajuan teknologi secara maksimal.

Strategi SO (Growth) yang tertuang dalam matriks SWOT, menunjukan bahwa terdapat 10 (sepuluh) strategi yang dapat dilakukan untuk mengembangkan UMKM di Desa nembol Kecamatan Mandalwangi Kabupaten Pandeglang diantaranya:

1. Mengikuti program pengembangan kredit bunga ringan untuk menambah modal usaha.

2. Menjaga hubungan baik dan memberikan pelatihan kepada karyawan

3. Melakukan pembaruan alat produksi

4. Melakukan pengembangan produk dengan tetap menjaga kualitas dan legalitas produk

5. Melakukan pemasaran dan promosi secara online

6. Menjaga aset dengan baik

7. Memperhatikan kondisi pasar dan peluang pasar

8. Mengikuti pembinaan pengembagan program UMKM baik yang diadakan oleh pemerintah maupun pihak swasta.

9. Menyediakan bahan baku yang berkualitas

10. Memanfaatkan sarana dan prasarana yang sudah disediakan Dinas Koperasi dan UMKM Kabupaten Pandeglang.

\section{Simpulan}

Berdasarkan hasil analisis dan pembahasan yang telah diuraikan sebelumnya, maka dapat disimpulkan bahwa terdapat permasalahan yang dihadapi para pelaku Usaha Mikro Kecil dan Menegah yang ada di Desa Nembol Kecamatan Mandalawangi Kabupaten Pandeglang antara lain aspek Permodalan, Produksi, 
Teknologi, Pemasaran, SDM, Birokrasi, Sarana dan Prasaran, serta Sosial dan Ekonomi. Selain itu strategi yang tepat dilakukan dalam upaya pengembangan UMKM di Desa Nembol adalah Strategi SO (Growth). Strategi SO (Growth) merupakan strategi yang memanfaatkan kekuatan yang ada untuk meningkatkan keunggulan kompetitifnya.

Terdapat beberapa saran dan rekomendasi dalam upaya pengembangan UMKM di Desa Nembol Kecamatan Mandalawangi Pandeglang antara lain pertama, UMKM perlu lebih memanfaatkan akses modal melalui perbankan atau instansi lain yang menawarkan program bunga lunak demi pengembangan usaha dalam bentuk pengembangan produk, pembaruan peralatan produksi, perluasan pasar, serta peningkatan kemampuan tenaga kerja melalui pelatihan. Kedua, UMKM dapat menggunakan Strategi SO (Growth) Strategi, dalam mengembangkan usahanya, yaitu dengan memanfaatkan kekuatan yang ada untuk meningkatkan keunggulan kompetitifnya. Ketiga, pemerintah daerah Desa Nembol perlu lebih mengsosialiasikan program pengembangan UMKM dan pembaruan regulasi yang mengatur kegiatan UMKM. Keempat, pemerintah daerah Desa Nembol perlu terus memfasilitasi sarana dan prasarana yang diperlukan dalam pengembangan UMKM dengan tetap menjaga stabilitas perekonomian. Kelima, perlu dilakukan penelitian yang lebih luas yaitu pada UMKM keseluruhan sektor, tidak hanya sektor pengembangan saja.

\section{Referensi}

Dafta Potensi Usaha Mikro Kecil dan Menengah Desa Nembol Kecamatan Mandalawangi Pandeglang Tahun 2020.

Fahrial, F., Utama, A. S., \& Dewi, S. (2019), Pemanfaatan Corporate Social Responsibility (CSR) terhadap Pembangunan Perekonomian Desa, Jurnal Wawasan Yuridika, Vol. 3 No. 2, pp. 251-264.

Hamid, R. S., \& Ikbal, M. (2017), Analisis Dampak Kepercayaan pada Penggunaan Media Pemasaran Online (E-Commerce) yang Diadopsi oleh UMKM: Perspektif Model DeLone \& McLean, Jurnal Manajemen Teknologi, Vol. 16 No. 3, pp. 310337.

Hamid, R. S., \& Ikbal, M. (2017), Pemberdayaan Pemuda Melalui Program Remaja Pintar Berbasis Ekonomi Kreatif Desa Lera Kecamatan Wotu Kabupaten Luwu Timur, RESONA: Jurnal Ilmiah Pengabdian Masyarakat, Vol. 1 No. 1. pp. 39-45.

Qamaruddin, M. Y., Sapar, S., Risal, M., \& Hamid, R. S. (2019), STRATEGI SIAPA MAU KERJA APA DALAM PENGEMBANGAN MODEL QUADRUPLE HELIX SINERGITAS ANTARA PEMERINTAH, PERGURUAN TINGGI, INDUSTRI, DAN MASYARAKAT, Jurnal Manajemen STIE Muhammadiyah Palopo, Vol. 4 No. 2. Pp. 13-23.

Ukkas, I. (2017), Strategi dan Upaya Pengembangan Usaha Mikro Kecil Menengah (UMKM), BERKEMAJUAN: JURNAL PENGABDIAN PADA MASYARAKAT, Vol. 1 No. 1, pp. 24-27.

Sugiyanto, S., Putri, A., \& Kartolo, R. (2021), Potensi Kekayaan Intektual Pada Pemberdayaan Umkm Dan Koperasi Kota Tangerang Selatan, Proceedings Universitas Pamulang, Vol. 1 No. 1. pp. 502-520.

Supardi, S., Nugraha, N. M., Susanti, N., Sumantri, M. B. A., \& Mukhlis, T. I. (2021), PELUANG DAN PERUBAHAN CARA BERPIKIR SAAT PANDEMIK 
(Pengabdian Kepada UMKM Binaan Kadin Provinsi Jawa Barat), Jurnal Pengabdian Dharma Laksana, Vol. 3 No. 2, 162-168.

Suhardjo, A. J. (2008), Geografi Pedesaan Sebuah Antologi, Ideas Media, Yogyakarta.

Goso, Samsul Bachri, (2016), IMPLEMENTASI PEMBERDAYAAN USAHA EKONOMI MIKRO KECIL DAN MENENGAH (UMKM), Jurnal Manajemen STIE Muhammadiyah Palolpo, Vol. 2, No.1. pp. 1-10. 